\title{
THE EFFECTIVENESS OF WORD JIGSAW STRATEGY ON STUDENTS' VOCABULARY MASTERY OF DESCRIPTIVE TEXT
}

\author{
Erniyanti Nur Fatahhela Dewi \\ Department of English Education, Faculty of Educational Sciences. \\ Syarif Hidayatullah State Islamic University Jakarta, Indonesia \\ efatahheladewi@gmail.com
}

\begin{abstract}
The aim of the present study was to find out the empirical evidence whether Word Jigsaw Strategy on students' vocabulary achievement of descriptive text was effective to be used in teaching vocabulary at the eighth grade of SMP PGRI 1 Ciputat. This present study was quantitative method with a quasi-experimental design. The sample of this study consisted of 25 students from VIII-3 class for Experimental Group and 25 students from VIII-4 in the controlled group. This present study, for the experimental class was taught by using Word Jigsaw as strategy in teaching Vocabulary Mastery, while controlled class was taught without Word Jigsaw. The research instrument was test that consisted of pre-test and posttest form. The technique used in collecting data was quantitative with t-test. The result of $t$ test (post-test) showed that the mean score of experimental group $(M=72,80)$ was higher than control group $(M=57,60)$, and independent-samples t-test which values of the sig 2tailed was 0,2\% or 0,002 and 0,002 <0,05. Thus, it was concluded that Word Jigsaw Strategy was effective on students' vocabulary mastery of descriptive text.
\end{abstract}

Keywords: Word Jigsaw Strategy, Vocabulary Mastery, Descriptive Text.

Vocabulary is one of the most important language elements that has a crucial position in understanding and requiring the language itself. If someone has limited vocabulary, it means that he has a big trouble to master the language skills. Mastering vocabulary is not easy. It takes time to master the practical real life needs such as word collocations, phrasal verbs, idioms, proverbs and regional differences in vocabulary usage. To make the students remember the vocabulary easily, the teachers have to use different methods and techniques beside substitution drill and word memorizing. Moreover, Thornburry (2016) argued that without grammar very little can be conveyed, without vocabulary nothing can be conveyed. It seems to indicate that vocabulary is the center in English learning process because vocabulary is a part of other aspects and skills. Although, students master in grammar aspect, we cannot say that they master in English if they have problems in vocabulary. Hence, vocabulary should be added in English learning process.

In fact, during the Integrated Teaching Practice Program (Praktik Profesi Keguruan Terpatu), writer found out that the students at the Eighth-grade of SMP PGRI 1 Ciputat have difficulties on English Vocabulary. They felt that to remember vocabulary is 
difficult. It is impossible for them to memorize English words. Further, it is not an easy task for teachers to teach vocabulary because of the limited ability of the students. So it is needed for teachers to apply an $<$ | 22 enjoyable learning situation to enhance students' interest in learning English. So, the teacher should be creative to decide an appropriate strategy to teach vocabulary. To overcome students' difficulties there are some ways that can be applied in teaching Vocabulary. One of them is by using graphic organizers especially Word Jigsaw. Stamper (2006) argued that graphic organizer especially Word Jigsaw provides the opportunity to the students to explore more about words. Hence, word jigsaw strategy seems beneficial to improve students' vocabulary mastery.

Moreover, Francis and Simpson (2009) suggested word jigsaw is part of graphic organizer which is one of alternative strategy to teach vocabulary. As known, many students got difficult to memorize many vocabularies especially junior high school students who have to know two thousand words. Using word jigsaw students will get interest to learn more about vocabulary knowledge. Stamper (2006) stated word jigsaw will help students to explore the meaning of word and use unfamiliar words. Students will practice to use dictionary to find the meaning of words and apply them in a sentence. Therefore, students will apply the word's meaning by using the word in the sentence about themselves, in a question and in an opinion.

In this study, the writer conducted the Word Jigsaw strategy on students' vocabulary achievement of descriptive text. The writer chose the descriptive text because it is learned by Eighth grade as stated in curriculum 2013. Masitoh and Suprijadi (2015) argued that descriptive text is one of genre texts which is one of texts that have to be taught to Junior High School students. It is hoped that students in junior high school will communicate each other in oral and written form of communication. To write descriptive text, students have to know every single word that they use to describe something or describe about. It means students have to master vocabulary. Furthermore, Word Jigsaw strategy seems appropriate to expand vocabulary on descriptive text. By using it, students will learn not only the meaning of the words but also the description of the words.

Previous related studies about strategy, technique, and method in enhancing vocabulary achievement have been widely conducted. The first written by Nurlia (2017) who find reading authentic materials has positive impact on students' vocabulary mastery. Next, Hervinia (2015) that found Graphic Organizers Strategy was effective to improve students' vocabulary mastery of recount text. Also, Umasugi, Bugis and Handayani (2018) found that scramble game is effective to be implemented in improving the students' vocabulary. Therefore, different from those previous studies, this present study would use word jigsaw strategy to enhance students' vocabulary mastery of descriptive text. Furthermore, the study is aimed to find out the significant difference of students' vocabulary improvement taught with word jigsaw and without word jigsaw.

\section{METHOD}

In this study, the writer conducted a quantitative research. The method in this investigation that the writer used Quasiexperimental. It is reasonable to use quasiexperimental design since James, Millan and Sally (2006) argued that quasi experiment designed to determine the effectiveness of a direct manipulation of condition. It is in line 
with the objective of this study which is to obtain the empirical evidence of the effectiveness of the Word Jigsaw to teach vocabulary.

Moreover, quasi-experimental study had experimental group and controlled group. In accordance, Fraenkel, Wallen and Hyun (2011) asserted that the writer matched the subject in the experimental and control groups on certain variables in quasi experimental design. Pre-test was given to both the controlled and experimental group at the eighth graders of Junior High School SMP PGRI 1 Ciputat to measure the condition before treatment. Next, the treatment was given to the experimental group by using word Jigsaw while the treatments of the controlled group were given by lecturing. After conducting the treatment, the test was given to both groups as the posttest. The scheme of this model is:

Table 1. Research Design

\begin{tabular}{lccc}
\hline Group & $\begin{array}{c}\text { Pre- } \\
\text { test }\end{array}$ & Treatment & $\begin{array}{c}\text { Post- } \\
\text { test }\end{array}$ \\
\hline $\begin{array}{l}\text { Experimental } \\
\text { Group }\end{array}$ & $\mathrm{T} 1$ & $\mathrm{X}$ & $\mathrm{T} 2$ \\
\hline Control & $\mathrm{T} 1$ & & $\mathrm{~T} 2$ \\
Group & & & \\
\hline
\end{tabular}

(Source: Sugiyono, 2015)

In which,

T1 : pre-test for experimental group

T2 : post-test for experimental group

T1 : pre-test for controlled group

T2 : post-test for controlled group

$\mathrm{X}$ : treatment by Word Jigsaw

\section{Subject of the research}

The population of this research was the Eighth-grade students of SMP PGRI 1 Ciputat. The Eighth-grade is divided into eight classes. In selecting the sample, writer used a convenience sampling. Frankel et al. (2011) explained that convenience sampling technique means that the writer took sampling from a group who are conveniently available and permitted by the school to be involved in the study. The samples of the research were the students of VIII-4 as the controlled group class and VIII-3 as the experimental class. Each class consists of 25 students.

\section{Instrument of Data Collection}

An instrument is a tool to gather data of the study. The instrument used in this study was a test. Ary, Jacobs and Asghar Razavieh (1972) argued that tests are valuable measuring instruments for educational research. Therefore, the role of the test is important in collecting data. In this study, the test given is vocabulary test. There are so many ways to test vocabulary, such as multiple choice, cloze test, matching items, set items, and others.

In this study, the writer used vocabulary test in the form of multiple choices, matching items, and cloze tests. It consisted of 25 items (15 multiple choices, 5 matching items, and 5 cloze tests). This test used in both pretest and posttest. In scoring the objective test, the correct answer was counted one point using formula;

$$
\mathrm{S}=\mathrm{R} / \mathrm{N} \times 100
$$

In which,

S: score

$\mathrm{R}$ : Total number of right answer

$\mathrm{N}$ : Total Number of Item

\section{Procedure of Intervention}

Teaching vocabulary by using Word Jigsaw strategy was done by the writer in six meetings. Below are the brief explanations about the teaching and learning process to improve vocabulary by using Word Jigsaw;

1) First meeting, Students were explained what they were going to do. The writer also explained that they would learn 
vocabulary mastery by using Word Jigsaw for next four meetings. Then, the pre-test was given to the students in order to know the students' competence in understanding the vocabulary of $\ll$ | 24 descriptive text on the pretest's result.

2) Second meeting, students were asked to find out the new vocabularies from the text and displaced them to the Word Jigsaw. In this part, students described the definition of word including its synonym and antonym.

3) Third meeting, students were given the text of completing the paragraph about people. Then, students were asked find out the new vocabularies about people either from the text and other sources. Students inputted the new vocabularies to the Word Jigsaw and understood them through it.

4) Fourth meeting, students were given the text of completing the paragraph about animal. They also were asked to find out the new vocabularies about animal either from the text and other sources. Students inputted the new vocabularies to the Word Jigsaw and understood them through it.

5) Fifth meeting, students were given the text of completing the paragraph about thing. They also were asked to find out the new vocabularies about thing either from the text and other sources. Students inputted the new vocabularies to the Word Jigsaw and understood them through it.

6) Sixth meeting, the writer reviewed vocabularies that have been given. At the end of the meeting, students were given a test, called posttest. The posttest was designed to know whether the use of Word Jigsaw as media in improving vocabulary was effective or not.

\section{Technique of Data Collection}

The data was collected by using pretest and posttest. Pretest was given before treatment in order to know and measure students' background of vocabulary related to descriptive text. The test was given to both experimental and controlled class. Moreover, after giving pretest, treatment implemented to experimental class in order to teach vocabulary of descriptive text. The given treatment was implementing Word Jigsaw to remember vocabulary for about 4 times.

During treatments, controlled class was taught vocabulary of descriptive text with no any treatment as experimental class. Controlled class will be taught without Word Jigsaw strategy. After giving some treatments, posttest was given in order to measure the ability of students after given different treatments to experimental and controlled class. The result of pretest and posttest will be compared in order to recognize whether word jigsaw affects students' vocabulary mastery.

\section{Technique of Data Analysis}

The writer conducted the tests, they were pre-test and post-test. The data were compared from the mean of the score from pre-test and post-test. After getting the data from the score, then the data was analyzed and processed by using statistic calculation of T-test formula with significance degree $5 \%$ and gained scores. In this regard, writer analyzed through SPSS (Special Package for the Social Sciences) 20 version.

T-test in this study used the average difference count score. It was done to know whether there was a significant difference or not between the experimental group and the controlled group. While the gained score way done to know the difference between pre-test and post-test score of each class of the experimental and the control groups. 
Gain scores were used to determine the increase or decrease in scores. They also needed to determine the effectiveness of the strategy used. However, prior to the tests the hypothesis necessary analysis prerequisite tests first, namely the distribution normality test and homogeneity test. Then, the writer measured how strong the effect of word jigsaw strategy's intervention using Cohen's theory formulation.

\section{FINDING}

Pre-test was given to both controlled class and experiment class in order to know students' vocabulary achievement before they were given any treatments. While posttest was given after treatments after six meetings treatments. Writer conducted the test result to the sample, the students of SMP PGRI 1 Ciputat. The result was used to get empirical evidence about the effect of using Word Jigsaw towards students' vocabulary achievement at the Eight-Grade of SMP PGRI 1 Ciputat. The result of the research is presented as data description based on the test result. The data analysis result obtained through vocabulary test.

Regarding to the vocabulary achievement test results, the average score of both experimental class and controlled class increased. However, the experimental class's score had increased more significantly rather than the controlled class. This can be seen through the range points gained by the two groups. The experimental class increased 30,48 points while the controlled class increased 8,48 points. The progress both classes can be seen in the diagram below:

\section{Figure 1. The difference between Students' Score in Experimental and 25 | > Controlled Class}

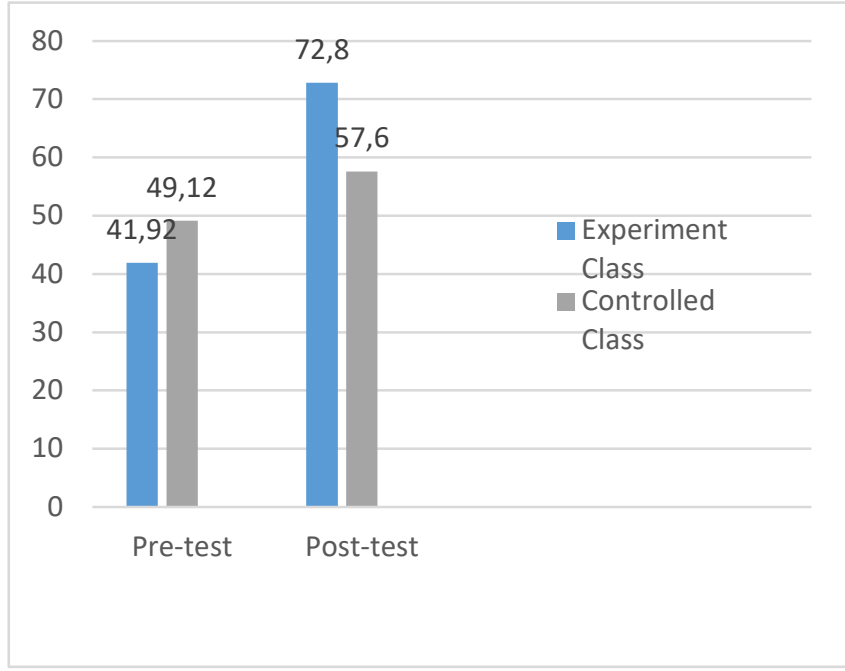

Moreover, the writer analyzed the test score of the experimental class and controlled class by calculating the formula $t-$ test. Before calculating the t-test value, to look at the difference of significant level, it was necessary to find out the normality value and homogeneity value of the data. The normality examination was needed to know whether the data has been normally distributed. Then, after getting the normality, the next step was calculating the data homogeneity.

Normality Testing was one of several requirements that have to be fulfilled before conducting t-test. It purposed to know whether the data from two classes have been normally distributed or not. The writer used Komogrov-Smirnov and Shapiro-walk to do the normality test. In order to get the answer of normality test, the data was normal distributed if the data has significance were 
above $5 \%(0.05)$. The result can be seen as

follow:

Table 2.

Normality Test of

Pre-test and Post-

test

\begin{tabular}{|c|c|c|c|c|c|c|c|}
\hline & \multirow[b]{2}{*}{ group } & \multicolumn{3}{|c|}{ Kolmogorov-Smirnov $^{3}$} & \multicolumn{3}{|c|}{ Shapiro-Wilk } \\
\hline & & Statistic & df & Sig. & Statistic & $\mathrm{df}$ & Sig. \\
\hline \multirow{2}{*}{ pretest } & Experiment Class & ,189 & 25 & ,022 & ,929 & 25 & ,082 \\
\hline & Controlled Class & ,166 & 25 & ,075 & ,911 & 25 & ,031 \\
\hline \multirow{2}{*}{ posttest } & Experiment Class & ,136 & 25 &, $200^{*}$ & ,958 & 25 & ,377 \\
\hline & Controlled Class & 119 & 25 & $200^{\star}$ & ,952 & 25 &, 273 \\
\hline
\end{tabular}

$\approx$. This is a lower bound of the true significance.

Based on the a. Lilliefors Significance Correction

table above, it

shows that; $\mathrm{P} \geq \alpha(0.022 \geq 0.05)$ and

$(0.075 \geq 0.05)$, it means that the pre-test score in this research was normally distributed. The scores of $\mathrm{P}$ can be checked through the Sig. in table of Kolmograv-Smirnov columns. While the result of post-test, related to the table that $\mathrm{P} \geq \alpha(0.200 \geq 0.05)$ and $(0.200 \geq$ $0.05)$. The data was higher in a

significance $\alpha=0.05$, It meant that the data was normally distributed because both of classes' significance were above 0.05 .

After doing the normality test, the writer did the homogeneity test in order to test the similarity of the sample in both classes. Levene statistic was used to calculate the homogeneity test. The result is presented as follows:

Table 3. Homogeneity Test of Pre-test and Post-test

\begin{tabular}{|c|c|c|c|c|c|}
\hline & & Levene Statistic & df1 & $d f 2$ & Sig. \\
\hline \multirow{4}{*}{ pretest } & Based on Mean & ,124 & 1 & 48 & ,726 \\
\hline & Based on Median & ,026 & 1 & 48 &, 873 \\
\hline & $\begin{array}{l}\text { Based on Median and with } \\
\text { adjusted df }\end{array}$ &, 026 & 1 & 46,440 & 873 \\
\hline & Based on trimmed mean & ,114 & 1 & 48 & ,737 \\
\hline \multirow{4}{*}{ posttest } & Based on Mean & 1,643 & 1 & 48 & ,206 \\
\hline & Based on Median & 1,523 & 1 & 48 & 223 \\
\hline & $\begin{array}{l}\text { Based on Median and with } \\
\text { adjusted df }\end{array}$ & 1,523 & 1 & 46,401 & ,223 \\
\hline & Based on trimmed mean & 1,644 & 1 & 48 & 206 \\
\hline
\end{tabular}

Based on the table above, it shows that the significance of pre-test between experimental class and controlled class was 0.726 . Therefore, the data of pre-test was homogenous because it was higher than 0.05. Moreover, the result of posttest significance between experimental and controlled was homogenous too, with the significance 0.206 .
After finishing the normality and homogeneity test, the data were calculated by using t-test to know the significant difference between students' vocabulary mastery of descriptive text in experimental class and controlled class. The data were from the mean score of post-test both experimental and controlled class. The standard significance was 0.05 . 
The result of hypothesis test by using SPSS 20 could be presented as follows:

Table 4. Pre-Test and Post Test Group Statistics

\begin{tabular}{llrrrr} 
& group & & Mean & Std. Deviation & Std. Error Mean \\
\hline \multirow{2}{*}{ pretest } & Experiment Class & 25 & $\mathbf{4 1 , 9 2}$ & $\mathbf{1 8 , 0 4 1}$ & $\mathbf{3 , 6 0 8}$ \\
& Controlled Class & 25 & $\mathbf{4 9 , 1 2}$ & $\mathbf{1 7 , 2 6 3}$ & $\mathbf{3 , 4 5 3}$ \\
\hline \multirow{2}{*}{ posttest } & Experiment Class & $\mathbf{2 5}$ & $\mathbf{7 2 , 8 0}$ & $\mathbf{1 4 , 0 0 0}$ & $\mathbf{2 , 8 0 0}$ \\
& Controlled Class & $\mathbf{2 5}$ & $\mathbf{5 7 , 6 0}$ & $\mathbf{1 7 , 9 6 3}$ & 3,593 \\
\hline
\end{tabular}

Based on the table above, it shows that each class had a similar total of students which is 25 . Results of post-test indicated that the mean score of the experimental class was 72.80 .
Meanwhile, the mean score of the controlled class was 57.60. It proved that the mean score of the experimental class was higher than the mean score of controlled

class

Table 5. T Test of Pre-Test and Post-Test Independent Samples Test

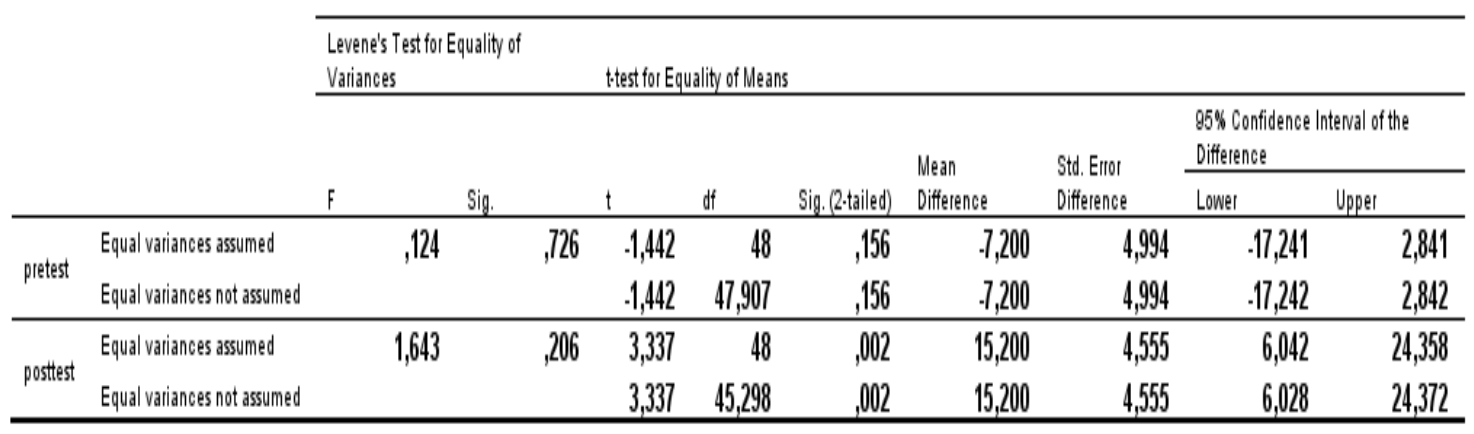

Based on the table above, it shows that for pre-test, $\mathrm{t}_{\mathrm{value}} \mathrm{was}-1,442$ and Sig. (2-tailed) was 0.156 and $95 \%$ confidence interval ranging from -17.241 to 2.841 . From the sig. (2-tailed), it can be seen the Sig. (2-tailed) was higher than 5\% (0.156> 0.05). It means that $\mathrm{H}_{0}$ was accepted and $\mathrm{H}_{1}$ was refused. While, for post-test, $\mathrm{t}_{\text {value }}$ was 3.337, and Sig. (2-tailed) was 0.002 and $95 \%$ confidence interval ranging from 6.042 to 24.358. From the sig. (2-tailed), it can be seen the sig. (2-tailed) was lower than $5 \%(0,002<0,05)$. So, $\mathrm{H}_{0}$ was refused and $\mathrm{H}_{1}$ was accepted. It means that Word Jigsaw Strategy was effective to improve students' vocabulary mastery of descriptive text.

In order to strengthen the result of $t-$ test, the writer used size effect by Cohen, the calculation as follows:

$$
\begin{aligned}
& \mathrm{d}=\frac{(\text { mean of group } A-\text { mean of gropu } B)}{\text { pooled Standard Deviation }} \\
& \mathrm{d}=\frac{76-56.64}{24.15}
\end{aligned}
$$


$\mathrm{d}=0.801$

It could be concluded that the size effect was 0.801 . It meant that the size effect was a moderate effect. The result from calculating the data is $t_{0}=2.778$ and $<<\mid 28 t_{t}=2.021$. It meant, $t_{o}$ higher than $t_{t}$ in significant $5 \%$. So, the null hypotheses were rejected and the alternative hypotheses was accepted.

\section{DISCUSSION}

The study aimed at investigating the effectiveness of Word Jigsaw Strategy on Students' Vocabulary achievement, especially on Descriptive Text. Mastering vocabulary is essential to learn language. It was reasonable since Keshta and Al-Faleet (2013) argued that vocabulary is a vital part of language that students need to master regarding to communicate effectively. Mastering vocabulary is also the ability to grasp meaning of utterances and sentences. It was necessary skill to strengthen reading and listening comprehension. This can positively impact overall academic success, especially to learn descriptive text. In other word, vocabulary was important to master in order to learn descriptive text. However, many strategies that could be used to improve vocabulary achievement. One of strategies was word jigsaw strategy. Stamper (2006) introduced Word jigsaw which is part of graphic organizer which is one of alternative strategy to teach vocabulary. As known, many students got difficult to memorize many vocabularies especially junior high school who have to know two thousand words. Using word jigsaw students will get interest to more learn about vocabulary knowledge. Hence, word jigsaw stimulates and motivate students to improve their vocabulary mastery.
To achieve the objective of the study, writer adopted the experimental approach where there were two equivalent groups which are the experimental group and control group. Each group included 25 students, conveniently available and permitted by the school SMP PGRI 1 Ciputat to be involved in the study. Both of experiment and control group were given pre-test, four meetings in treatments, and post-test. From the scores of both groups, there is a difference between students' achievement of the score in pre-test (experimental and controlled class) and the controlled class had the higher mean score than experimental class. In post-test, experimental class and controlled class were increased better than in pre-test. But, for this session, the experimental class had the higher mean score than the controlled class. It means that there is a significant score of experimental class and controlled class.

In addition, based on the calculation of the t-test, from post-test data, $\mathrm{t}_{\text {value }}$ was 3.337, and Sig. (2-tailed) was 0.002 and $95 \%$ confidence interval ranging from 6.042 to 24.358 . From the sig. (2-tailed), it can be seen the sig. (2-tailed) was lower than $5 \%(0,002<0,05)$. Therefore, Ha was accepted and Ho was rejected. Thus, there is a significant difference between the students' score in students' Vocabulary test used Word Jigsaw and the students' score in Vocabulary test without using Word Jigsaw Strategy at the Eight-grade students of SMP PGRI 1 Ciputat. It means students' who learn descriptive text using Word Jigsaw Strategy had a significant effect on vocabulary compared to those who did not learn descriptive text by using Word Jigsaw. According to the study, there is a significant effect of using Word Jigsaw strategy on students' Vocabulary 
achievement of the descriptive text. From the data analysis of the study, it can be known that Word Jigsaw strategy can give a significant effect of students' Vocabulary because the score of students' vocabulary test after being taught by using Word Jigsaw is higher than before the writer gave the treatment.

Furthermore, the present study supports the previous studies that Graphic Organizer such as Word Jigsaw is found very helpful and effective to teach the vocabulary (Hervinia, 2015; Shoari \& Farrokhi, 2014; Al-Hinnawi, 2012; Monroe, 1997). In addition, this strategy can also be implemented in all subjects but it depends on students' level and needs. Based on implementation, it can be summed up that using Word Jigsaw is effective to improve students' Vocabulary of descriptive text especially for the Eightgrade students at SMP PGRI 1 Ciputat.

\section{CONCLUSION}

Word Jigsaw Strategy was applied to improve students' vocabulary achievement of descriptive text. It was applied to VIII-3 class students of SMP PGRI 1 Ciputat who were acted as experimental group. Meanwhile, VIII-4

was chosen as control group. It was purposed to compare students' vocabulary mastery that taught using Word Jigsaw Strategy and which not taught using Word Jigsaw Strategy.

Moreover, T-test was done by using pre-test score and post test score. The result of pre-test showed that Ho was accepted and $\mathrm{H}_{1}$ was refused. It was because from the sig. (2-tailed) was higher than 5\% $(0.156>0.05)$. But, the result of t-test of post-test showed that $\mathrm{H}_{0}$ was refused and $\mathrm{H}_{1}$ was accepted. It was since the sig. (2tailed) we can see the sig. (2-tailed) was lower than $5 \%(0,002<0,05$. So, based on the result of post-test. It could be concluded that Word Jigsaw Strategy was effective to improve students' vocabulary mastery on descriptive text at eight grade students of SMP PGRI 1 Ciputat.

Furthermore, English teachers can apply Word Jigsaw Strategy as one strategy to teach vocabulary mastery. Hence, Word Jigsaw Strategy requires students to be more active. It is easier to apply new vocabularies. Teachers also need to pay attention to the step of this strategy. Not only teacher, students also can use this strategy outside the class. Practicing with partner will be effective for students to understand the other's intention.

\section{REFERENCES}

Al-Hinnawi, A. N. (2012). The Effect of the Graphic Organizer Strategy on University Students' English Vocabulary Building. English Language Teaching, 5(12), 62-69.

Ary, Donald., Jacobs, Lucy Cheser., \& Asghar Razavieh, (1972). Introduction to Research in Education. (5th ed.). California: Harcourt Brace College.

Fraenkel, J. R., Wallen, N. E., \& Hyun, H. H. (2011). How to design and evaluate research in education. New York: McGraw-Hill Humanities/Social Sciences/Languages.

Hervinia, A. B. (2015). The Effectiveness of Graphic Organizers for Teaching Vocabulary of Recount Text Quasi Experimental Study at the Eighth Graders of SMP N 6 Semarang 
in the Academic Year 2015/2016 (Doctoral dissertation, Universitas Negeri Semarang).

James H, Mc., Millan and Sally Shumacer (2006). Research in Education. Boston: Person, Education. Inc.,

Keshta, A. S., \& Al-Faleet, F. K. (2013). The effectiveness of using puzzles in developing Palestinian tenth graders' vocabulary achievement and retention. Humanities and Social Sciences, 1(1), 46-57.

Masitoh, S., \& Suprijadi, D. (2015). Improving Students'ability in Writing Descriptive Text Using Genre Based Approach (Gba) at the Eighth Grade Students of Smp Islam Terpadu Fitrah Insani. ELTIN JOURNAL, Journal of English Language Teaching in Indonesia, 3(1).

Monroe, E. E. (1997). Using Graphic Organizers To Teach Vocabulary: How Does Available Research Inform Mathematics Instruction?.

Nurlia, V. (2017). The Effectiveness of Reading Authentic Materials in Improving Students'vocabulary Mastery (Bachelor's thesis, Perpustakaan Ilmu Tarbiyah dan Keguruan).

Shoari, E., \& Farrokhi, F. (2014). The effects of graphic organizer strategy on improving iranian efl learners' vocabulary learning. Research in English Language Pedagogy, 2(1), 71-82.

Sugiyono, (2015). Metode Penelitian Kuantitatif, Kualitatif Dan R\&D. Bandung: Alfabeta.

Stamper, J. B. (2006). Vocabulary-building: Graphic Organizers \& Mini-lessons. Scholastic.

Thornbury, S. (2006). How to teach vocabulary. Pearson Education India.

Umasugi, S., Bugis, R., \& Handayani, N. (2018). The Scramble Game In Improving Students' vocabulary at the Seventh Grade of MTS LKMD Sawa. Jurnal Retemena, 3(2), 1-10. 